\title{
EGYETEMI ÜZLETI INKUBÁCIÓ LEHETŐSÉGEI ELMARADOTT TÉRSÉGEKBEN
}

\author{
(University Busiess Incubation: \\ Opportunities in Less Favoured Regions)
}

BAJMÓCY ZOLTÁN

Kulcsszavak:

egyetemi üzleti inkubátor inkubáció pre-inkubaició elmaradott térségek Szeged

A tanulmány az egyetemi üzleti inkubációt vizsgálja, amely az egyetem-helyi iizleti szféra közötti kapesolatokat javitami képes gazdaságfejlesztési eszköz. Az egvetemi iizleti inkubátorok cilapitásának kérdése az elmútt években napirendre keriilt hazänkban is, àm a sikeres kullföldi gyakorlatok szinte kivétel nélkull fejlett térségekböl valók, ami megnehezíti az adaptációt.

Jelen tanulmány elsôként ätrekinti az egyetemekhez, kunatóintézerekhez kötớdö inkubcició sajútosságuit a szolgáltatási funkciót és a spin-off képzödés folyamatát kiemelve. E-t követö́n egy szegedi KKV mintán vizsgáljuk az inkubációval szembeni kisvállalkozói igénveket. Az elméleti ăttekintés és az empirikus vizsgálat eredményei alapján a cikk harnadik részében felvaizoljuk azoka a tényezöket. amelyek figyelembe vérelét elengedhetetlennek tartjuk az elmaradott térségekben indítandó programok megtervezésekor.

\section{Bevezetés}

Az egyetemek és kutatóintézetek közvetve és közvetlenül is jelentös befolyással lehetnek egy-egy adott térség fejlódésére, amelyet számos sikertörténet (Cambridge, Szilícium Völgy, Tsukuba, Oulu) támaszt alá (Varga 2004). Ugyanakkor egy tudáskoncentráló intézmény jelenléte önmagában csak lehetőséget jelent, a közfinanszírozású kutatóhelyek és a helyi üzleti szféra' kapcsolatrendszerének kiteljesedése nem törvényszerü.

Az egyetemek és kutatóintézetek regionális szerepe igen sokrétü lehet: a helyi kereslet növelésétöl, a direkt technológiai hatásokon át a regionális miliöhöz történö hozzájárulásig (Goldstein-Renault 2004, Morgan 2002). A régebb óta kutatott visszacsatoló (kiadási) hatások mellett egyre nagyobh lị̣̂lmet kapnak az elörecsatoló (tudáshoz kapcsolódó) hatások is, amelyck a huluill cröforrús színvonalának javulásában, az intenzívebb kutatás-fejleszlési aktivitíbiıl é a lérség vonzóképességének növekedésében csapódnak le (Armstrong-Iry/r) 2010), Varga 2004). Mind gyakrabban fogalmazódik meg, hogy az egyetemck oktalási és kutatási funkciója csak az eredmények gazdasági hasznosulásának funkciójával együtt tud hatékonyan kiteljesedni és gazdasági hatásokat generálni (Etzkovitz et al 2000).

Ebbe a fogalmi keretbe illeszkedik az egyetemi üzleti inkubáció (EÜI) koncepciója, amely a technológia-intenzív induló vállalkozások egyik meghatározó támogatási formájává vált. AZ EÜI lényege nem az egyetemi (kutatóintézeti) tulajdonlásban, 
Bajmócy Zoltán : Egyetemi üzleti inkubáció lehetőségei elmaradott térségekben

Tér és Társadalom 20. évf. 2006/3. 31-47. p.

hanem a tudásbázis helyi gazdasági hasznosításának céljában és az egyetemhez kötődő szolgáltatások meglétében áll. Az inkubáció eredeti koncepciójának megfelelöen az EÜI az induló innovatív vállalkozásokat növekedésük kezdeti, legsérülékenyebb szakaszán segíti át, abban a reményben, hogy a támogatás a későbbi növekedés eredményeképp társadalmilag megtérül (Bajmócy 2004). Számos sikertörténet bizonyítja, hogy ezt hatékonyan, ráadásul az egyetem céljait is támogatva képes megtenni (Celine-Garnsey 2000, Tornatzky et al 2003). Azonban a sikeres példák szinte mindig fejlett, centrum térségekböl származnak.

Napjainkban Kelet-Közép-Európa átmeneti gazdaságaiban is napirendre került az egyetemekhez kötỏdỏ inkubátorok létrehozásának kérdése. Magyarország vidéki nagyvárosaiban világosan látszik, hogy egy EÜI projektet nem tudnak az egyetemek önállóan megvalósítani, csak a helyi önkormányzatokkal történő együttmüködéssel és feltehetöleg EU-s támogatások bevonásával. Az egyetemi inkubációt tehát helyi gazdaságfejlesztési beavatkozásként lehet és kell értelmezni. Szüikséges megvizsgálni egy ilyen beavatkozás racionalitását, illetve feltárni azokat a sajátosságokat, amelyek figyelembe vétele nélkül az egyetemi inkubáció adaptálása nem lehetséges.

Jelen cikkben elöször áttekintjük az egyetemi inkubáció, mint helyi gazdaságfejlesztési eszköz sajátosságait vezérfonalként az inkubátor szolgáltatási funkcióját, illetve a spin-off képzödés folyamatát használva. Ezt követően a Szegedi kistérségben müködỏ kis- és középvállalkozásokból álló mintán vizsgáljuk az egyetemi inkubáció iránti kisvállalkozói igényeket. A cikk harmadik részében az elméleti áttekintés és az empirikus vizsgálat eredményeinek felhasználásával megadjuk az elmaradott térségekben múködö, illetve kialakítandó egyetemi inkubátor programok legfontosabb sajátosságait, és felhívjuk a figyelmet azokra a tényezökre, amelyeket a fejlett térségekben mükỏdő minták adaptálásakor feltétlenül figyelembe kell venni.

\section{Az egyetemi üzleti inkubáció, mint gazdaságfejlesztési eszköz}

Az üzleti inkubáció gyüjtőfogalom, amely számos különbözö gyakorlati megvalósulási formát takar. Közös vonás ugyanakkor, hogy induló vállalkozásoknak nyújtanak növekedésük kezdeti időszakában (az inkubációs időszak alatt) átmeneti jelleggel komplex szolgáltatásokat. A legjellemzóbb szolgáltatástípusok: a múködési (inkubációs) tér, az ügyviteli szolgáltatások, a tỏkéhez jutás segítése és hálózatosodás ösztönzése (Carayannis-Zedtwitz 2005). Mindez a gyakorlatban az eszközök számos fajtáját jelentheti az ipari parkoktól a tudományos parkokon át a technológiai központokig (CEC 2002).

Az üzleti inkubáció értelmezésének központi eleme az induló vállalkozások részére biztosított speciális környezet, miliö (és ily módon a térbeli közelség), amely megnöveli túlélési esélyüket, javítja fejlödési képességüket. Az inkubáció minden esetben egy folyamat, amelynek egyik eleme a támogatott vállalkozás értéknövekedése, a mások oldalon pedig az inkubátorba történő befektetés, illetve ennek közvetlen vagy közvetett megtérülése áll. Az inkubátor teljesítménye, amelyet a támogatott cég növekedésével $^{2}$ mérnek, három összetevőből áll: a szelekciós teljesítmény (beléptetési 
Bajmócy Zoltán : Egyetemi üzleti inkubáció lehetőségei elmaradott térségekben Tér és Társadalom 20. évf. 2006/3. 31-47. p.

TÉT XX. évf. 2006 - 3

Egyetemi ïzleti inkubáció ...

politika), a monitoring és a szolgáltatás-nyújtás intenzitása és az eröforrások biztosításának szintje (Hackett-Dilts 2004a).

Ezt az összefüggést implicit módon már korábban is feltételezték. Az empirikus munkák általában valamely funkció müködésének a teljesítményre gyakorolt hatását tesztelték, illetve a sikeres példákból igyekeztek következtetéseket levonni a menedzselés helyes gyakorlatára vonatkozóan (Barrow 2001; Hackett-Dilts 2004b; Rice 2002). Az egyetemi inkubátorokkal kapcsolatban ezen a téren Sarfraz Mian $(1996 ; 1997)$ munkássága volt úttörö, aki átfogó modellt dolgozott ki az egyetemi inkubătorok müködésének értékeléséhez.

Ha az egyetemi üzleti inkubátorra, mint gazdaságfejlesztési (vállalkozásfejlesztési) eszközre tekintünk, akkor meg kell állapítani, hogy mely problémák jelenthetik a beavatkozás alapját, milyen esetekben lehet hatékony (más programoknál hatékonyabb) fejlesztési eszkơz. A tartós versenyképesség alapját jelentő regionális innovációs kapacitás ösztönzésére két alapvetö megközelítést mutat be Döry és Rechnitzer (2002): az endogén és a mobilitás-orientált stratégiákat. A modell logikája igen jól illeszkedik a Rechnitzer (1998) nyomán közismertté vált kereslet-orientált, illetve kínálatorientált fejlesztési megközelítéshez. Az egyetemek inkubációs szerepvállalása elsősorban endogén erőforrások kiaknázását jelenti, jóllehet a tudományos parkok az egyetem speciális imázsát kihasználva gyakran vonzanak külső befektetöket is.

Az egyetemi inkubátorok létrejöttének alapja egyrészt az egyetemek növekvő szerepvállalása a helyi gazdaságfejlesztésben, másrészt az egyetemek saját szervezeti érdekei. Az egyetemek ugyanis legalább három szinten versenyben állnak egymással: a hallgatókért, a kutatókért, illetve a kutatási forrásokért. Így igyekeznek olyan teljesítményt felmutatni és olyan imázst kialakítani maguk körül, amely segíthet a fenti területeken versenyben maradni. Másrészt, ha az egyetem hajlandó tökebefektetésre is, akkor - a kutatási irányultságtól függően - jelentős bevételekre tehet szert, amelynek jogi alapját a Bayh-Dole típusú szabályozás hazánkban is megteremtette. Az állami ỏsztönzés ténye egyáltalán nem meglepő, hiszen maga a tudományos kutatás is nagyrészt állami finanszírozású, így ennek gazdasági hasznosulása (a befektetés megtérülése) alapvetỏ érdek (Buzás 2003).

Az egyetemek az inkubációs folyamatban komplex módon jelennek meg: az inkubátor alapítását szorgalmazó szervezetként (szponzorként), amely a helyi gazdaság fellendülését és szervezeti érdekeinek megvalósulását várja, szolgáltatás nyiijtóként, múködési teret és speciális technológiai szolgáltatásokat biztosítva, végül a vállalkozók anyaintézményeként, hiszen azok jelentös része akadémiai berkekböl kerül ki. Ennek megfelelően az egyetemi inkubáció vizsgálata során jól elkülöníthetó az egyetem szolgáltatásnyújtó szerepe, illetve a spin-off cégek alakulásának és fejlödésének folyamata.

Sok esetben a piacon értékesíthetö termék kifejlesztéséhez szükséges szolgáltatások nem vagy nem megfelelő minőségben állnak rendelkezésre a lokális gazdasági környezetben. Az egyetemek olyan inspiráló közeget, felszereléseket, laboratóriumokat, képzéseket, speciális szolgáltatásokat képesek nyújtani a vállalkozóknak, amelyekhez a magánszektor vállalkozásai saját szervezeti kereteiken belül nem 
Bajmócy Zoltán : Egyetemi üzleti inkubáció lehetőségei elmaradott térségekben

Tér és Társadalom 20. évf. 2006/3. 31-47. p.

tudnának hozzáférni (Mian 1996). Ezen szolgáltatások jelentős részét a piaci szereplök még hosszabb távon sem képesek vagy hajlandóak biztosítani. Különösen igaz ez a kevésbé fejlett térségekben.

1. TÁBLÁZAT

A legjellemzöbb technológiai és egyetemhez kötödö inkubátor-szolgáltatások

(The Most Common University-related and Other Technology Services of Incubators)

\begin{tabular}{|c|c|}
\hline $\begin{array}{l}\text { Technológiai } \\
\text { szolgáltatások }\end{array}$ & $\begin{array}{l}\text { Egyetemhez kötödö } \\
\text { szolgáltatások }\end{array}$ \\
\hline $\begin{array}{l}\text { Elemzö, tesztelö, minősítö } \\
\text { laboratóriumok }\end{array}$ & $\begin{array}{l}\text { Egyetemi alkalmazott igénybevétele } \\
\text { tanácsadóként }\end{array}$ \\
\hline Környezeti és minőségi rendszerekkel & Egyetemi hallgatók alkal mazása a \\
\hline $\begin{array}{l}\text { kapcsolatos tanácsadás } \\
\text { Szabadalmi és licenc tanácsadás }\end{array}$ & $\begin{array}{l}\text { támogatott vállalkozásoknál } \\
\text { Egyetemi image }\end{array}$ \\
\hline $\begin{array}{l}\text { Támogatásokhoz való hozzájutás } \\
\text { segítése }\end{array}$ & Könyvtár igénybevétele \\
\hline $\begin{array}{l}\text { Kutatóintézeteknek történö bedolgo- } \\
\text { zás segítése }\end{array}$ & Laboratóriumok igénybevétele \\
\hline $\begin{array}{l}\text { Technológia figyelés, benchmarking, } \\
\text { audit }\end{array}$ & $\begin{array}{l}\text { Nagy teljesítményủ számítástechnikai } \\
\text { eszközök }\end{array}$ \\
\hline Technológiai vásárok & $\begin{array}{l}\text { Egyetemhez kapcsolódó } \mathrm{K}+\mathrm{F} \text { tevé- } \\
\text { kenység }\end{array}$ \\
\hline Teljesítmény értékelés & Technológia-transzfer programok \\
\hline Bemutató központok és tesztuizemek & $\begin{array}{l}\text { A támogatott vállalkozások alkalma- } \\
\text { zottainak képzése }\end{array}$ \\
\hline
\end{tabular}

Forrás: Bellini (2002, 31) és Mian (1996, 327).

Az egyetemhez kötődő technológiai inkubátorok szinte mindegyike speciális többnyire egy adott iparág sajátosságaira koncentráló - szolgáltatásokat nyújt, de a legjellemzőbb technológiai szolgáltatás-fajták megadhatóak (1. táblázat). A szolgáltatások természetszerüleg nem csak az akadémiai spin-off cégeknek, hanem a helyi gazdaság többi innovatív vállalkozásának is felkínálják. Ez teljesen természetes magatartás, hiszen így könnyebben biztosítható az a kritikus tömeg, amely lehetővé teszi az inkubátor fenntartható mủködtetését.

Az endogén eröforrások kiaknázása szempontjából különös jelentősége van az egyetemeknek és kutatóintézeteknek köszönhető tudáskoncentráció gazdasági hasznosításának. A kevésbé fejlett térségek mindennapos problémája, hogy az eredmények gyakran nem helyben hasznosulnak, vagy egyáltalán nem jutnak el a magánszektor vállalataihoz (Buzás 2003; Inzelt 2004). A térségen kívüli hasznosulás elsösorban akkor lehetséges, ha a kutatás már kézzelfogható eredményt tud felmutatni, azaz kodifikált tudás (technológia) átadásáról van szó. Ám az egyetemi szférában képződő eredmények továbbdolgozása igen gyakran hallgatólagos tudáselemek átadását is megköveteli, amely interakciók speciális jellemzökkel bírnak és megkövetelik a 
térbeli közelséget (Lengyel B. 2004). Ilyenkor gyakran döntő kérdés a feltaláló további közremüködése.

A kutató bevonására a további fejlesztésekbe három mód kínálkozik: egyrészt tanácsadóként alkalmazhatják annál a vállalatnál, amely továbbviszi a fejlesztéseket, másrészt a magánszféra szponzorálhatja a további fejlesztéseket, így azokat vállalati pénzekböl, de az egyetem infrastruktúráját kihasználva folytathatja a feltaláló, harmadrészt a feltaláló új vállalkozást hozhat létre az ötlet magvalósítására.

Ugyanakkor a spin-off folyamat középpontjában nem feltétlenül az egyetem vagy kutatóintézet alkalmazottja áll, a ,fószereplö" lehet maga a szellemi termék, egy végzett vagy jelenlegi hallgató, $\mathrm{PhD}$ hallgató is. Az egyetem szempontjából azonban a spin-off képződés mindig a tudás gazdasági hasznosulását jelenti, és amenynyiben az testet ölt valamilyen szabadalomban vagy más oltalom alá tartozó szellemi termékben, úgy a licencbe adással szembeni alternatív megoldást jelöli.

A „kipörgés” (spin-off) folyamatát idóben elkülöníthetö szakaszokra lehet bontani, amely szakaszok más és más kihívásokat állítanak az alapító elé (Clarysse et al 2005):

- Az elsö kihívás a technológia megerősítése, amikor elválik, hogy az ötlet kecsegtet-e üzleti hasznosíthatósággal. Ekkor még magának a technológiának a finomításán van a hangsúly.

- A folyamat második lépcsöjében az üzleti ötlet kimunkálásáe a föszerep. Attól, hogy a technológia müködőképes, még nem biztos, hogy a piac elfogadja.

- A harmadik lépcsó a létrejött vállalkozás növekedési pályára állítása (1. ábra).

\section{1. ÁBRA}

A ,kipörgés" (spin-off) folyamata

(The Spin-off Process)

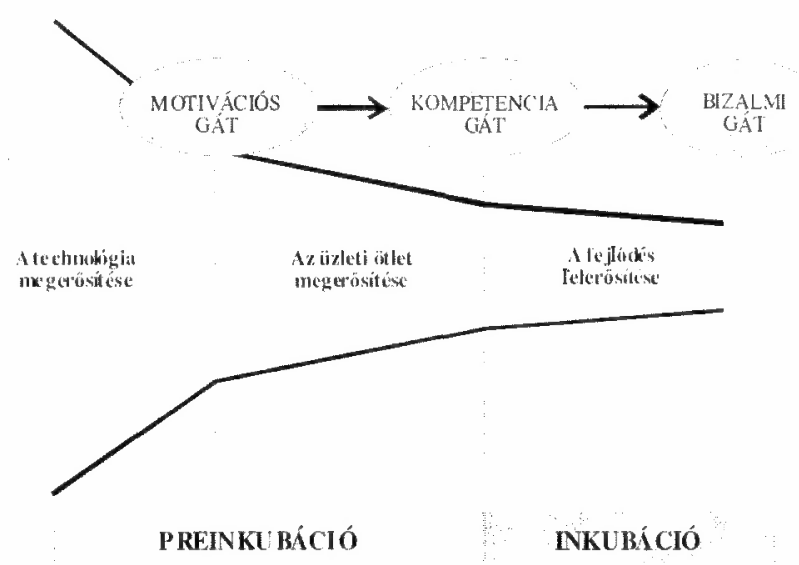

Forrás: Clarysse et al (2005) és Buzás (2004) alapján sajăt szerkesztés. 
Bajmócy Zoltán : Egyetemi üzleti inkubáció lehetőségei elmaradott térségekben

Tér és Társadalom 20. évf. 2006/3. 31-47. p.

36 Bajmócy Zoltán

TÉT XX. évf. 2006 — 3

Az egyes szakaszok közötti átmenet általában nem zökkenőmentes, így az ötleteknek csupán kis részéből lesz gyorsan növekvő technológia-orientált kisvállalkozás. Elsőként a kutató motivációs korlátba uutközhet: az egyébként hasznosítható ötlet ellenére sem akar részt venni az üzleti életben (Buzás 2004). Ez egyáltalán nem meglepö, hiszen a kutatók számára a vállalkozásalapításnak hatalmas alternatív költségei vannak. Egyrészt a biztos állás elvesztése, másrészt az „elvesztegetett idố, hiszen a fejlesztés eredményei nem viszik elöre akadémiai karrierjében, abból általában nem származnak publikálható eredmények. Ezt kővetỏen az alapító gyakran szembesül azzal, hogy nincsenek megfelelő kompetenciái a vállalkozás menedzseléséhez. Végül pedig a megalakult cég szembesül a legtöbb induló vállalkozást érintô problémával, hogy nincs renoméja, nincsenek referenciái, nem jönnek a megrendelések (bizalmi gát).

Az inkubáció feladata a fent említett problémák orvoslása. Látni kell azt, hogy az egyetemi inkubáció klasszikus feladata, a spin-off cég növekedésének gyorsítása (elbukásának megakadályozása) a folyamat sokadik lépése. Különösen igaz ez Kelet és Közép-Európa országaira, ahol a spin-off képződés egyelőre inkább kivétel, mint megszokott folyamat. Így az egyetemi inkubációt meg kell elöznie a preinkubációnak, amelynek kulcs kihívása: a tudás gyakorlati hasznosításának ösztönzése és az üzleti ötlet kimunkálásának segítése, gyorsítása.

A folyamat ösztönzésre különböző stratégiákat alkalmaznak az európai kutatóintézetek és egyetemek (Clarysse et al 2005). Az egyik lehetöség a vállalkozói aktivitás általános ösztönzése, ahol a legfontosabb cél, hogy minél több vállalkozás alakuljon. Ezek a cégek általában kereset-kiegészítést jelentenek, vagy önfoglalkoztatást, ritka köztük az eröteljes nővekedésre képes cég (low selective model). A második alapvetô stratégia esetén a cél a nagy növekedési potenciállal bíró spin-off cégek létrejötte, amely adott esetben az egyetem számára jobb megoldásnak tünik, mint a szellemi termék licencbe adása (supportive model). A megtérülést a helyi gazdaság fejlódése és az egyetem felé irányuló későbbi kutatási megbízások jelentik. A harmadik eset az egyetem vagy kutatóintézet jelentős pénzügyi befektetését jelenti a spin-off vállalkozásba. Ekkor általában a cég értéknövekedésén, tehát tôkenyereség realizálásán van a hangsúly (incubator model).

A jelenlegi szabályozási környezet mellett Magyarországon elvileg bármelyik modell megvalósítható lenne. Ugyanakkor a gyakorlatban csak az elsỏ két megoldás tủnik valós alternatívának. Míg az első eset a pre-inkubáció és az inkubáció közötti lazább kapcsolatot is megenged, addig a második esetén a két szakasz szoros egymásra épülése és összefonódása szükséges.

\section{Az egyetemi inkubáció iránti kisvállalkozói igények Szeged példáján}

Az egyetem-ipar kapcsolatokra potenciálisan alkalmas helyi vállalkozói réteg körében 2004 és 2005 során felmérést végeztủnk a Szegedi Tudományegyetemen ${ }^{3}$. Az egyetem és a kistérség sajátosságai számos ponton megegyeznek a többi vidéki egyetemei várossal, amely biztosítja az eredmények bizonyos szintủ általánosíthatóságát, de természetszerüleg csak a tipikusan helyi jellegzetességek szem elött tartásával. 
Szeged az Európai Unió egyik legalacsonyabb GDP/fő-vel rendelkező régiójának központja, de ezen belül Csongrád megye pontosan Szegednek köszönhetően a $\mathrm{K}+\mathrm{F}$ input-mutatói tekintetében messze felülmúlja az országos átlagot. A városban markáns klaszterek jelenléte nem mutatható ki. Foglalkoztatottsági-, vállalati- és export-LQ adatok alapján bizonyos hagyományos tevékenységek (élelmiszerfeldolgozás, textilipar, kereskedelem), egyes tudás-alapú szolgáltatások (egészségügyi-ellátás, oktatás, jogi szolgáltatás) és a $\mathrm{K}+\mathrm{F}$ tevékenység országos átlag fölötti koncentrációja figyelhető meg (Patik-Deák 2005). A Szegedi Tudományegyetem 11 karára mintegy 30000 hallgató és $600 \mathrm{PhD}$ hallgató jár, ám múszaki szakok nincsenek jelen a képzési palettán. Az egyetem igen komoly tudományos kapacitással rendelkezik föleg természet-, orvos- és gyógyszerésztudományi területen. Ehhez járul az MTA Szegedi Biológiai Központja, a Bay Zoltán Alkalmazott Biotechnológiai Intézet és a Gabonakutató, mint legföbb kutatóintézetek.

Az empirikus vizsgálat során közel 1000 Csongrád megyei (elsősorban a Szegedi kistérségben elhelyezkedö) vállalatnak küldünk kérdőívet, amelyböl 170 értékelhető érkezett vissza. A kutatás céljának megfelelöen a mintában a térség gazdasági szerkezetéhez képest felülreprezentáltak a 10-50 föt foglalkoztató, a feldolgozóipari tevékenységet végzó, illetve az innovatív vállalatok.

A vállalkozásokat két csoportra, az innovatívak és a nem innovatívak klaszterére különítettük el. Innovatívnak tekintettünk egy vállalkozást, amennyiben az alábbiak közül legalább az egyik teljesül:

- van saját $\mathrm{K}+\mathrm{F}$ részlege,

- az elmúlt évben adtak $\mathrm{K}+\mathrm{F}$ megbizást valamely külső cég részére,

- valamely külföldi partnerrel tartósan együttmüködnek termék- vagy technológia-fejlesztésben.

A 170-es mintából elsőként kivettük a 14 nagyvállalatot, majd azokat a vállalkozásokat, amelyeknél a fenti kategóriák valamelyike kapcsán hiányzott a válasz. Így egy 146 elemü kis- és középvállalkozásokból álló mintával dolgoztunk tovább. A minta vállalkozásainak 32,9\%-át (48 db) tekintjük a fentiek értelmében innovatívnak és $67 \%$-ot ( $98 \mathrm{db})$ nem innovatívnak.

Jelen empirikus vizsgálat alapvetô célja, hogy képet nyerjünk az innovatív és nem innovatív vállalkozások közötti különbségröl a tekintetben, hogy fejlesztésük kapcsán milyen intenzitással léphetnek fel nem kívánatos kiszorító, torzító hatások. Másrészt megkíséreltük felrajzolni az inkubációs szolgáltatásokat fontosnak ítélő vállalkozások alapvető jellemzöit, harmadrészt pedig azt vizsgáltuk, hogy az inkubációs szolgáltatás milyen más szolgáltatások iránti igényekkel jár jellemzően együtt. Ennek során három hipotézist fogalmaztunk meg:

- Hipozézis 1: Az innovatív KKV-k jelentős régión kívüli piacokkal rendelkeznek, így egy adott iparágbeli vállalkozás gyors (térségi átlagot jóval maghaladó) növekedése nem feltétlenül jelenti más helyi vállalkozások bevételeinek csökkenését (a beavatkozás nem feltétlenül okoz erỏteljes iparágon belüli átrendezödést). 
Bajmócy Zoltán : Egyetemi üzleti inkubáció lehetőségei elmaradott térségekben Tér és Társadalom 20. évf. 2006/3. 31-47. p.

- Hipotézis 2: Az inkubációs szolgáltatásokat fontosnak ítélö vállalkozások karakterisztikája megadható, az ilyen KKV-k bizonyos közös jellemzőkkel bírnak.

- Hipotézis 3: Az inkubációs szolgáltatások iránt igény együtt jár más egyetemi szolgáltatások (laboratórium , K+F stb.) iránti igényekkel.

Az 1. hipotézis tesztelése során megvizsgáltuk, hogy a minta vállalkozásai milyen mértékben tekinthetök tradednek, azaz a vállalkozások milyen arányban képesek termékeiket és szolgáltatásaikat régión kívüli piacokon is értékesíteni (2. táblázat). Jól látható, hogy a nem innovatív vállalkozások legnagyobb része a helyi piacra termel, és ezt kőveti szorosan az ország Dél-Alföldi régión kívưli része. Ezzel szemben az innovatív vállalkozások majdnem $30 \%$-ának az országhatáron túl vannak a legfontosabb piacai, és csupán 13\%-uk elsödleges piaca van helyben.

\section{TÁBLÁZAT}

A legfóbb vevök és szállitók elhelyezkedése (The Distribution of Main Cutomers and Suppliers)

\begin{tabular}{lcccc}
\hline & $\begin{array}{c}\text { Legföbb vevök } \\
\text { (érvényes adatok } \\
\text { \%o-ában) }\end{array}$ & \multicolumn{2}{c}{$\begin{array}{c}\text { Legföbb szállitók } \\
\text { (érvényes adatok } \\
\% \text {-ában) }\end{array}$} \\
\cline { 2 - 5 } & $\begin{array}{c}\text { Nem } \\
\text { innovatív } \\
(n=96)\end{array}$ & $\begin{array}{c}\text { Innovatív } \\
(n=47)\end{array}$ & $\begin{array}{c}\text { Nem } \\
\text { innovativ } \\
(n=83)\end{array}$ & $\begin{array}{c}\text { Innovatív } \\
(n=40)\end{array}$ \\
\hline $\begin{array}{l}\text { Helyben (megyében) } \\
\text { Megyén kívül a Dél- }\end{array}$ & 39,6 & 12,8 & 41,0 & 15,0 \\
$\begin{array}{l}\text { Alföldi régióban } \\
\text { Dél-Alföldön kívül }\end{array}$ & 14,6 & 6,4 & 6,0 & 7,5 \\
$\begin{array}{l}\text { Magyarországon } \\
\text { Külföldön }\end{array}$ & 35,4 & 53,2 & 43,4 & 45,0 \\
\hline Összesen & 10,4 & 27,7 & 27,7 & 32,5 \\
\hline
\end{tabular}

* Az adatok nem a vevök és szállítók számára, hanem az értékesítés és vásárlások összegére vonatkoznak.

Forrás: Saját szerkesztés.

A gazdaságfejlesztés szemszögéböl igen lényeges kérdés, hogy a térségèn kívüli értékesítéshez milyen mértékben társulnak térségen kívüli beszerzések, ugyanis az eröteljes összefüggés az export-multiplikátor hatás alacsony szintjére utalna. Ebben a tekintetben jelentős különbségek mutatkoznak a két csoport között. A nem innovatív vållalatok körében szignifikáns szimmetrikus kapcsolatokat találtunk a vállalatok értékesítésének és beszerzésének legföbb térsége között ${ }^{4}$. Ha feltesszük, hogy a külföldi értékesítés felé haladva a termék egyre versenyképesebb, akkor ismérveink felfoghatóak ordinális skálán mértnek. Ez esetben a Spearman-féle rangkorrelációs együttható értéke: $\mathrm{r}=0,430$ (Sig 0,000), amely azt jelzi, hogy a nem innovatív vállalatok csoportja esetén a térségen kivuuli értékesítéshez nagy valószínüséggel társul régión kívüli beszerzés. $\mathrm{Az}$ innovatív $\mathrm{KKV}-\mathrm{k}$ esetén nem találtunk szignifikáns kapcsolatot a beszerzés és értékesítés legfőbb térsége között. 
Bajmócy Zoltán : Egyetemi üzleti inkubáció lehetőségei elmaradott térségekben Tér és Társadalom 20. évf. 2006/3. 31-47. p.

TÉT XX. évf. 2006 - 3

Egyetemi üzleti inkubáció...

Elsö hipotézisünket tehát elfogadjuk, az innovatív KKV-k csoportjának megalkotásakor egy traded (régión kívülre is értékesíteni képes) vállalati kört sikerült lehatárolni, ráadásul a térségen kívüli értékesítés esetükben nem feltétlenül párosul eröteljes importfüggőséggel. Mindez azt jelzi, hogy egy esetleges fejlesztési beavatkozás hatása jóval erőteljesebb lehet, és nem feltétlenül okoz eröteljes torzító hatásokat a lokális térség piacán.

A 2. hipotézis tesztelése során az egyetemhez kötödö inkubációt (inkubátor vagy tudományos park) fontosnak itélö vállalkozásokat vizsgáltuk ${ }^{6}$. A szolgáltatást a válaszadók 43,6\%-a ítélte fontosnak, és várakozásainkkal ellentétben nem volt lényegi különbség a két klaszter között. A nem innovatív KKV-k esetén 55,4\%, míg az innovatív KKV-k körében 41,7\% tartotta fontosnak. Ennek magyarázatát két tényezőben látjuk:

- A nem innovatív KKV-k egy jelentös csoportja szinte minden vállalkozásfejlesztési szolgáltatás iránt erőteljes érdeklődést mutat, ám e mögött, úgy tủnik, nem mindig az áll, hogy ténylegesen is szükségük van arra a szolgáltatásra (Imreh 2005).

- Feltételezhetö, hogy a vállalkozók az inkubátorházakról, illetve az ipari parkokról meglevő ismereteiket kivetítve az egyetemi inkubációtól is inkább költségelönyöket, mint magas értékhozzáadást közvetítő szolgáltatásokat várnak.

További statisztikai vizsgálatot csak a teljes mintán tudtunk végezni, ugyanis csak itt állt rendelkezésre megfelelő elemszám, ráadásul e tekintetben nincs olyan lényeges különbség a két csoport között, amely igazolta volna a klaszterenkénti vizsgálatot.

Az empirikus adatok alapján nem tudtuk felrajzolni az inkubációt fontosnak ítélő vállalkozások karakterisztikáját. Sem a tevékenység alapvető jellemzöi (tevékenység föcsoport, vevök és szállítók elhelyezkedése, beszállítói tevékenység), sem a vállalkozás kora, sem stratégiai céljai nem csökkentik bizonytalanságunkat annak megbecslésekor, hogy a vállalkozás fontosnak ítéli-e az egyetemhez kötődö inkubációs szolgáltatást ${ }^{7}$. A második hipotézist tehát elvetjuik, az inkubációt fontosnak ítéló vállalkozások karakterisztikája jelen felmérés alapján nem adható meg. Ennek oka a fentebb említett két tényezỏ mellett még abban állhat, hogy a vizsgált vállalati kör igényei és inkubációval szembeni elvárásai heterogének.

A harmadik hipotézis tesztelésekor azt vizsgáltuk, hogy az inkubáció pozitív megitélése együtt jár-e valamely más szolgáltatás iránti igénnyel (3. táblázat). Amenynyiben a nominális skálán mért ismérvek közôtti kapcsolatot mérö $\lambda$-mutató pozitív szignifikáns értéket ad, úgy az adott szolgáltatás igénybevétele iránti hajlandóság esetén valószínübb, hogy a vállalkozás az inkubáció iránt is érdeklödik. Három esetben találtunk kapcsolatot, amelyből kettő viszonylag szoros volt. Amennyiben egy vállalkozás fontosnak tartja versenyelőnyei megerösödéséhez egy regionális kockázati töketársaság felállítását, illetve az egyetemtöl $\mathrm{K}+\mathrm{F}$ szolgáltatást kíván igénybe venni, úgy valószínúbb, hogy fontosnak ítéli meg egy egyetemi inkubátor létesítését is. Az összefüggés koránt sem ilyen erőteljes, de kimutatható a laboratóriumi szolgáltatásokkal kapcsolatban is. 
Bajmócy Zoltán : Egyetemi üzleti inkubáció lehetőségei elmaradott térségekben Tér és Társadalom 20. évf. 2006/3. 31-47. p.

\section{TÁBLÁZAT}

Az inkubáció és egyéb szoláltatások iránti igények közötti összefüggés

(Correspondence between the Need for Incubation and other Services)

\begin{tabular}{|c|c|c|c|}
\hline & & Kapcsolat & Lambda \\
\hline \multirow{6}{*}{$\begin{array}{l}\text { Egyetemhez } \\
\text { köthetö } \\
\text { szolgáltatások }\end{array}$} & $K+F$ szolgáltatások & & 0,368 (Sig. \\
\hline & & van & $0,000)$ \\
\hline & & & (dep. Incub)* \\
\hline & Laboratóriumi szolgáltatások & gyenge & $\begin{array}{c}0,190 \text { (Sig. 0.03) } \\
\text { (dep. Incub)* }\end{array}$ \\
\hline & KKV specifikus képzések & nincs & nem szignifikáns \\
\hline & $\begin{array}{l}\text { Technológiai információk } \\
\text { gyüjtése és értékelése }\end{array}$ & nincs & nem szignifikáns \\
\hline \multirow{7}{*}{$\begin{array}{l}\text { Általános } \\
\text { vállalkozás- } \\
\text { fejlesztési } \\
\text { szolgáltatások }\end{array}$} & $\begin{array}{l}\text { Regionális kockázati tóketár- } \\
\text { saság megszervezése }\end{array}$ & van & $\begin{array}{c}0,404 \text { (Sig. } \\
0,001 \text { ) } \\
\text { (dep. Incub)* }\end{array}$ \\
\hline & $\begin{array}{l}\text { Hálózatok és klaszterek helyi } \\
\text { szervezése }\end{array}$ & nincs & nem szignifikáns \\
\hline & $\begin{array}{l}\text { Piaci információk gyüjtése és } \\
\text { értékelése }\end{array}$ & nincs & nem szignifikáns \\
\hline & $\begin{array}{l}\text { Pályázati információk gyüj- } \\
\text { tése és értékelése }\end{array}$ & nincs & nem szignifikáns \\
\hline & Müszaki tanácsadás & nincs & nem szignifikáns \\
\hline & $\begin{array}{l}\text { Befektetési és hitel tanács- } \\
\text { adás }\end{array}$ & nincs & nem szignifikáns \\
\hline & $\begin{array}{l}\text { Informatikai tanácsadás } \\
\text { Üzleti tervezés }\end{array}$ & $\begin{array}{l}\text { nincs } \\
\text { nincs }\end{array}$ & $\begin{array}{l}\text { nem szignifikáns } \\
\text { nem szignifikáns }\end{array}$ \\
\hline
\end{tabular}

* A kapcsolat nem szimmetrikus. A függő változó: az inkubáció.

Forrás: Saját szerkesztés.

Harmadik hipotézisünket tehát elfogadjuk, kapcsolatot találtunk az egyetemi inkubáció, illetve más egyetemhez kötódő szolgáltatások iránti igények között (elsösorban a $\mathrm{K}+\mathrm{F}$ szolgáltatások esetén). A regionális kockázati tőketársaság és az inkubáció iránti összefüggés is ezt támasztja alá, hiszen a kockázati tőke a gyorsan növekvő, innovatív vállalkozások tipikus finanszírozási formája.

Az empirikus vizsgálat legfontosabb következtetése, hogy az innovatív KKV-k fejlesztése várhatóan kisebb torzító hatásokkal jár, mint a nem innovatívaké, továbbá kiviláglik, hogy az inkubáció iránti érdeklődés meglehetősen heterogén. Valószínủsíthetö, hogy egy ègyetemhez kötödő inkubátor vagy tudományos park indításakor a jelentkezők egy része pusztán költségelönyöket fog keresni és nem esik bele a tényleges célcsoportba. Ugyanakkor jelen van a KKV-k egy olyan köre, amely komplex egyetemhez kötődỏ szolgáltatáscsomagot igényel. Mindez a beléptetési szürủ fontosságára, a beléptetési kritériumok pontos és következetes betartására hívja fel a figyelmet. 
Bajmócy Zoltán : Egyetemi üzleti inkubáció lehetőségei elmaradott térségekben Tér és Társadalom 20. évf. 2006/3. 31-47. p.

TÉT XX. évf. $2006 \mathbf{\square} 3$

Egyetemi üzleti inkubáció...

41

\section{Egyetemi üzleti inkubáció lehetöségei elmaradott térségekben}

Egy adott térség vállalkozásai többnyire csak hosszabb idő alatt változtatják meg jelentósen viselkedésúket, így az empirikus vizsgálat eredményei bizonyos útmutatással szolgálhatnak a ma még csak potenciális vállalkozások majdani viselkedésérỏl is. E mellett a korábban említett hasonlóságok miatt a szegedi eredmények részint igazak lehetnek más vidéki egyetemi városokban is. Ezen elmaradott térségek mindegyikére igaz, hogy a gazdasági és intézményi struktúra számos sajátossága nem teszi lehetővé a sikeres külföldi tapasztalatok egy az egyben történő átvételét. Jelen fejezet célja, hogy a kevésbé fejlett régiók számára megfogalmazza azokat a legfontosabb szempontokat, amelyek figyelembe vétele véleményünk szerint elengedhetetlen a sikeres egyetemi inkubátor programok indításához. Megállapításaink a ,kiket" és a „hogyan" kérdések köré szervezzük, ugyanis meglátásunk szerint az inkubáció sikeressége az ezen kérdésekre adott megfelelỏ válaszok eredménye.

$\mathrm{Az}$ egyetemi inkubátorok célcsoportját a spin-off cégek, a potenciális tudásalapú vállalkozók (különösen a kutatók, végzett hallgatók, $\mathrm{PhD}$ hallgatók), és a térségben múködő innovatív KKV-k alkotják. Míg Nyugat- és Észak-Európa egyes országaiban és az Amerikai Egyesült Államokban a spin-off cégek létrejötte viszonylag spontán és tömeges folyamat, addig Magyarországon és más kevésbé fejlett térségekben ez egyelöre szórványos jelenség (Buzás 2003). A spin-off cégek létrejöttének támogatását célul tüzỏ kormányzati programok vizsgálata során azt láthatjuk, hogy Budapest és vonzáskörzetének kiemelkedö túlsúlya mellett csupán néhány olyan vidéki egyetemi város van, ahol jelentösebb számban volt támogatást elnyeró projekt (4. táblázat). Szeged igen jó teljesítménye mellett Debrecen és Pécs azok a helyek, ahol egy induló egyetem inkubátor program komolyan számolhat a spin-off vállalkozásokkal.

\section{TÁBLÁZAT}

A Tech-start pályázatok nyertes projektjei 2004-2005-ben

(Supported Projects of the Tech-Start Tender in 2004-2005)

\begin{tabular}{lclc}
\hline \multicolumn{1}{c}{ Megye } & $\begin{array}{c}\text { Nyertes projektek } \\
\text { száma }(\mathrm{db})\end{array}$ & \multicolumn{1}{c}{ Város } & $\begin{array}{c}\text { Nyertes projektek } \\
\text { száma }(\mathrm{db})\end{array}$ \\
\hline Budapest & 72 & Budapest & 72 \\
Pest & 13 & Szeged & 20 \\
Csongrád & 22 & Debrecen & 9 \\
Hajdú-Bihar & 10 & Pécs & 7 \\
Baranya & 7 & Miskolc & 5 \\
Borsod-Abaúj- & 8 & Veszprém & 3 \\
Zemplén & 3 & Egyéb & 38 \\
Bács-Kiskun & 3 & & \\
Györ-Moson- & 3 & & \\
Sopron & 3 & & \\
Somogy & 10 & & 154 \\
Veszprém & 154 & Összesen & \\
Egyéb & & \\
\hline Összesen & & \\
\hline
\end{tabular}

Forrás: NKTH. 
Bajmócy Zoltán : Egyetemi üzleti inkubáció lehetőségei elmaradott térségekben

Tér és Társadalom 20. évf. 2006/3. 31-47. p.

Az innovatív cégek KKV szektoron belüli részaránya igen nehezen becsülhetö, és az alkalmazott definíciótól függỏen igen jelentősen változhat. Az azonban biztosnak látszik, hogy az elmaradott térségekben mủködő KKV-k innovációi inkább a máshol már alkalmazott technológiák, eljárások átvételén és módosításán alapszik, amelyet Baranya megyei empirikus vizsgálatok is alátámasztanak (Inzelt-Szerb 2003, 1015). A hazai egyetemvárosok mint tudásalkalmazó régiók esetén középtávon ebben nem várható változás: az egyetemi tudásbázis köré szerveződő viszonylag kevés élenjáró mellett az innováció fö iránya a minél gyorsabb technológiaátvétel (Lengyel 2003, 404).

Mindebből az következik, hogy az egyetemi üzleti inkubációt egy átgondolt és jól felépített pre-inkubációs stratégiának kell megelöznie. Egy egyetemi inkubátor létrehozása jelentös befektetést jelent, amelynek müködtetésében a fix költségek részaránya meglehetősen magas. A potenciális új belépők folyamatos jelenléte nélkül a program könnyen abba az irányba fordulhat, hogy a bennlevők megtartásával és a szolgáltatási színvonal folyamatos csökkentésével egy ingatlanügylet szintjére süllyed.

A szegedi minta vizsgálatából kiderült, hogy az innovatív vállalkozások támogatása várhatóan csökkenti azokat a kiszorító hatásokat, amelyek az inkubációval szembeni egyik leggyakoribb ellenérvként szoktak megjelenni, ugyanis bizonyos kevésbé életképes cégek támogatása más (nem támogatott) cégek bukását idézheti elö (CEC 2002; Peña 2004). Ez elsősorban azokban a szektorokban jelent problémát, amelyek erôsen függnek a helyi kereslettöl (Lengyel-Recchnitzer 2004). Ugyanakkor megjegyezzük, hogy a tudásalapú gazdaságban igen nagy szerephez jutnak a helyi szolgáltató szektorban müködő innovatív vállalkozások, amelyek annak ellenére, hogy helyi keresletet elégítenek ki és más helyi vállalkozásokat szoríthatnak ki, átlagon felüli növekedésre képesek és katalizálhatják a helyi fejlödést (Piech-Radosevic 2006).

További igen lényeges szempont a beléptetési szürök helyes megválasztása. A szegedi vállalkozások vizsgálatából kiderült, hogy az inkubáció iránt érdeklődő vállalkozók jelentős része valószínűsíthetően költségelőnyöket és nem magas értékhozzáadó képességgel bíró szolgáltatásokat keres. Ezt némiképp felerösítheti a kormányzati ösztönzési rendszer is: az egyetem vagy kutatóintézet területén múködö vállalkozások számára biztosított, általában $50 \mathrm{~m} \mathrm{Ft-ig} \mathrm{terjedő} \mathrm{adókedvezmény}{ }^{8}$. Bár a támogatás jól láthatóan innovatív vállalkozásokat céloz, mégis elterelheti a figyelmet az inkubációs funkciókról, és a parkszerúbben müködö, nagyobb vállalkozásokra fókuszáló intézmények (tudományos parkok) létrejöttét ösztönözheti.

A beléptetési (szelekciós) politika mellett az igen gyakran elhanyagolt és az értékelések kapcsán sokszor mellőzött kiléptetési politika is igen lényeges eleme az inkubációs folyamatnak. A kiléptetési politika hiánya általában pont ott jelenik meg gondként, ahol nincsen jelentős nyomás a potenciális új belépök felöl. Ekkor a bérleti díjak fenntartása érdekében a cégek akár 5-10 évig is az inkubátorban maradnak, amely ellentétes az inkubáció eredeti logikájával, az átmeneti támogatással. Adegbite (2001) ugyanakkor felhívja a figyelmet arra, hogy kevésbé fejlett térségekben az inkubátor elhagyását sokszor a megfelelő telephely hiánya akadályozza. 
Ennek orvoslása általában kettős: egyrészt a tudományos park jelentheti az inkubációs idöszakot követö megfelelő telephelyet, másrészt az inkubátor „feltöltése” után a befolyó összegekböl újabb épületet emelnek.

Mint minden vállalkozásfejlesztési program esetén, úgy az inkubációval kapcsolatban is igen eltérő gyakorlati megvalósulásokhoz vezethet a beavatkozás módja (hogyan). Ez ad alapot arra, hogy a kisvállalkozás-fejlesztés két eltérő paradigmáját (a piacfejlesztöt és a piachelyettesítőt) alkalmazzuk az üzleti inkubációra is (Bajmócy 2004). Ám a modell tisztaságát itt megzavarja, hogy bizonyos alapvetó inkubációs szolgáltatásokat a magánszektor szereplöi hosszabb távon sem tudnak biztosítani (tipikusan ilyenek az egyetemekhez kötỏdỏ szolgáltatások).

A piachelyettesítö megközelítés (substitute the market approach) gyakorlatilag elfogadja a fejlesztési probléma tartós fennállását és azokért cserébe próbál valamiféle kompenzációt nyújtani. A kifejlesztett szolgáltatásokat közpénzekből támogatott szervezetek nyújtják a kisvállalkozásoknak. Itt a probléma nem szünik meg, kezelése folyamatos donorfinanszírozást igényel. A piacfejlesztö megközelítés (facilitate the market approach) a helyben nem vagy nem megfelelö minőségben elérhető szolgáltatások piacának kifejlesztésére és a fenntarthatóságra összpontosít. A megfelelő szolgáltatás kifejlesztése után a magánszektor szolgáltatói idỏvel tiszta piaci körülmények között képesek müködni így a donorfinanszírozás csökkenthetö és végül megszüntethető (Kállay-Imreh 2003).

Piachelyettesitönek nevezhető az az inkubátor, ahol a magánszektor különösebb beleszólása nélkül, mintegy felülről-lefelé (top-down módon) határozzák meg a nyújtott szolgáltatások körét. A szolgáltatásnyújtás hosszú távon is donorfüggö, nincs törekvés a magánszektor szerepvállalásának erösítésére. Ez esetben gyakorlatilag bizonyos erőforrások szokásosnál alacsonyabb áron történő biztosításáról van szó (az ár egy részének a donorfinanszírozás terhére történő átvállalásával). Az inkubáció gyakorlatában ennek legszembeötlöbb jele, hogy a donorfinanszírozott program ${ }^{9}$ inkább fordul a donor, mint a piac felé. Ez azt jelenti, hogy a valós fejlesztési problémákat vagy fel sem ismerik, vagy nincsen mód a szükséges szolgáltatások kifejlesztésére, hiszen a donorfinanszírozás azt nem teszi lehetővé. Ennek kivédésére az inkubáció folyamatába és a szolgáltatási kör kialakításába valamilyen módon be kell vonni a piaci szereplőket is (Adegbite 2001).

A szolgáltatási kör meghatározása az inkubátorok üzemeltetésének talán legkritikusabb feladata. Ha az inkubátor túl kevés szolgáltatást nyújt, akkor igen hasonlatossá válhat egy irodabérleti ügylethez, amellyel az inkubáció lényege veszhet el. Ha az inkubátor túl sok szolgáltatás nyújtását tervezi, akkor nagy valószínúséggel olyan is lesz közötte, amellyel helyi magánszereplöket szorít ki a piacról. Az így létrejövő piactorzítás szintén ellentétben áll az inkubáció szándékaival.

A piacfejlesztö modellben a legnagyobb különbség a magánszektor szerepvállalásának megjelenése. A magántőke közvetlen szerepvállalása ritka (bár nem példa nélküli) a vállalkozás-/gazdaságfejlesztési célú inkubátoroknál, ugyanakkor a részben magántöke finanszírozta ügynökség szerepe maghatározó. Ez a szervezet segít a piaccal való megfelelö kapcsolat kialakításában, a szolgáltatási kör felállításában. 
Bajmócy Zoltán : Egyetemi üzleti inkubáció lehetőségei elmaradott térségekben

Tér és Társadalom 20. évf. 2006/3. 31-47. p.

Ez esetben a vállalkozások stratégiai elönyöket találnak az inkubátorban, amelyért fizetni hajlandóak. A szolgáltatás ellenértékének meghatározása az egyik legtöbbet vitatott vállalkozásfejlesztési módszertani kérdés. A teljes piaci ár megfizetésével valószínúleg a legrászorultabbak esnének ki a programból, az ingyenesség azonban gyakran alacsony színvonalú programokhoz vezet (Imreh 2005). Így az ár egy részének megfizetése tünik a legszerencsésebb megoldásnak, amely biztosítja, hogy a szolgáltatást azok vegyék igénybe, akiknek az valós értéket biztosít. Ez segít a fenntarthatóság kialakításában is, amely lehetövé teszi a donorfinanszírozás folyamatos csökkentését.

Az inkubáció magyarországi gyakorlata jelenleg a piachelyettesítő felfogást követi, amely nem egyedi az átmeneti országokban. Lalkaka (1997) kiemeli, hogy igen jelentös probléma ezekben az országokban a fenntarthatóság hiánya, illetve, hogy a program élére a hivatali bürokráciából választanak vezetôt. Pedig számos fejlödő országban, ahol az alapfeltételek még rosszabbak, sikeresen müködnek fenntartható, a fejlesztési problémákat hatékonyan kezelni képes technológiai inkubátor programok (Lalkaka 2002). Ugyanakkor a piacfejlesztés nem egyenlö az azonnali fenntarthatósággal. Annak elérése általában néhány évet vesz igénybe, ám a programot már induláskor célszerủ úgy tervezni, hogy a szolgáltatások, vagy a tökenyereség révén szerzett bevételek ${ }^{10}$ biztosítsák a folyamatos múködését és a szolgáltatási paletta szükséges megújitását.

\section{Összegzés}

A helyi tudáskoncentrációban rejlö lehetőségek jobb kihasználásának igénye hazánkban is aktuális téma, amelynek keretén belül megfogalmazódott az egyetemi inkubátorok létrehozásának lehetősége is. A sikeres külfföldi példák ugyanakkor fejlett térségekből származnak, amely megnehezíti azok átvételét.

Jelen tanulmányban elsỏként áttekintettük az egyetemi inkubátorok sajátosságait. Egy ilyen szervezet két legföbb funkciója a spin-off folyamat ösztönzése, illetve az egyetemhez kötődő szolgáltatások biztosítása. Ám amíg a spin-off képződés szórványos jelenség, addig az inkubáció csak egy átgondolt pre-inkubációs stratégiával együtt érheti el célját.

A cikk második részében empirikus vizsgálatot végeztünk a Szegedi kistérség kisés középvállalkozásainak körében az egyetemi inkubációval szembeni elvárások felderítése céljából. Az eredményekböl fény derült arra, hogy az innovatív kisvállalkozások ösztönzése esetén a támogatások nem kívánatos kiszoríto hatásai csökkenthetők. Az inkubációval szembeni igények sok esetben együtt járnak a $\mathrm{K}+\mathrm{F}$ szolgáltatások, a regionális kockázati tőketársaság és a laborok iránti igényekkel. Ugyanakkor nem sikerült felrajzolni az egyetemi inkubáció iránt érdeklődő vállalkozások karakterisztikáját, amely mögött az állhat, hogy a potenciális érdeklödők jelentỏs része nem valós szolgáltatásokat, hanem csupán költségelőnyt remél. Ez a beléptetési politika fontosságára hívja fel a figyelmet.

A cikk harmadik részében az elmaradott térségekben müködő, vagy indítandó egyetemi inkubátor programok sajátosságait vizsgáltuk, és igyekeztünk ráirányítani a figyelmet azokra a tényezőkre, amelyeket a fejlett térségekben müködö minták adaptálásakor feltétlenül figyelembe kell venni. 


\section{Jegyzetek}

' A nemzetközi szakirodalomban a közfinanszírozású kutatóhelyek és a helyi ùzleti szféra kapcsolataira rỏviden egyetem-ipar (university-industry) vagy akadémiai-ipari (academy-industy) kapcsolatként szokás utalni. Ennek megfelelöen jelen cikkben az egyetem-ipar kapcsolatok alatt valamennyi egyetem és közfinanszírozású kutatóhely és a gazdaság - nem csak ipari - szereplöi közti kapcsolatokat értjük.

${ }^{2}$ Növekedés alatt leggyakrabban a bevétel, a profit, illetve a foglalkoztatotti létszám növekedését szokás érteni, amely szempontok különböző eredményre vezethetnek.

${ }^{3}$ A kutatást (A Szegedi Tudományegyetem lehetőségei a tudásalapú helyi gazdaságfejlesztésben) Prof. Lengyel Imre vezetésével a Gazdaságtudományi Kar Közgazdaságtani és Gazdaságfejlesztési Intézete végezte.

A nominális skálán mért ismérvek közötti kapcsolat erösségének gyakran használt mutatója a $\lambda$-mutató, amelynek értéke 0 és 1 közé esik. Azt mutatja, hogy az egyik ismérv szerinti hovatartozás mennyiben csökkenti egy másik ismérv szerinti hovatartozás becslésekor elkövetett hiba valószínúségét. A nem innovatív KKV-k esetén: $\lambda=0,337$ ( $S i g .0,000$ ). Az innovatív KKV-k esetén a mutató értéke 0-hoz közeli és nem szignifikáns.

${ }^{5}$ A Spearman-féle rangkorrelációs együttható az ordinális skálán mért ismérvek közötti kapcsolat erősségét mutatja, értéke - 1 és 1 között változik, 0 esetén nincs kapcsolat.

${ }^{6}$ A vállalkozásoknak az egyetemhez kötődö inkubátor vagy tudományos park típusú szolgáltatás fontosságát kellett értékelni 1-7 skálán. Fontosnak ítélte az adott KKV a szolgáltatást, ha arra 5-7 értéket adott.

7 A $\lambda$-mutató értéke valamennyi jellemző esetén 0-hoz közeli és nem szignifikáns.

${ }^{8}$ A felsőoktatási intézmény, valamint a Magyar Tudományos Akadémia által alapított kutatóintézet kezelésében lévő terùleten működő adózó adózás elötti eredményét a $\mathrm{K}+\mathrm{F}$ ráfordítások 3-szorosával, maximum 50 millió forinttal csökkentheti (Forrás: http://www.apeh.hu/megyek/hajdu/ 09vallado2005_ta.htm).

${ }^{9}$ Ugyanez igaz a program felett bábáskodó szintén donorfinanszírozott ügynökségre.

${ }^{10}$ Amennyiben az inkubált cégekben részesedést is szerez az inkubátor. Ennek igen jó példája a dán "Innovation Environments" program, amely bekerült az Európai Unióban ajánlott legjobb gyakorlatok kơzé is (Forrás: www.techtrans.dk).

\section{Irodalom}

Adegbite, O. (2001) Business Incubators and Small Enterprise Development: The Nigerian Experience. Small Business Economics, 3.157-166. o.

Armstrong, H.-Taylor, J. (2000) Regional Economics and Policy. Third Editon. Blackwell Publisher, Oxford-Maiden, MA.

Bajmócy Z. (2004) Az üzleti inkubảció szerepe a vállalkozásfejlesztésben. Közgazdasági Szemle. 12. 1132-1150. o.

Barrow, C. (2001) Incubators. A Realist's Guide to the World's New Business Accelerutors. John Wiley \& Sons, New York.

Bellini, N. (2002) Business Support Services. Marketing and the Practice of Regional Innovation Policy. Oak Tree Press, Irealand.

Buzás N. (2003) Organizational Elements of Knowledge Transfer in Hungary: Towards a Functional System of Innovation. - Lengyel I. (ed.) Knowledge Transfer. Shall and Medium-Sized Enterprises, and Regional Development in Hungary. JATEPress, Szeged. 32-46. o.

Buzás N. (2004) A vállalkozói szellem szerepe a spin-off cégek alapításában. - Czagány L.-Garai L. (szerk) A szociális identitás, az információ és " piıc. SZTE Gazdaságtudományi Kar Közleményei, JATEPress, Szeged. 257-266. o.

Carayannis, E.G.-von Zedtwitz, M. (2005) Architecting GloCal (global-local) Real-Virtual Incubator Networks (G-RVINs) as Catalysts and Accelerators of Entrepreneurship in Transitioning and Developing Economies: Lessons Learned and Best Practices from Current Development and Business Incubation Practices. Technovation. 2. 95-110. 0.

CEC (2002) Benchmarking of Business Incubators. Final Report. Center for Strategy \& Evaluation Services. European Comission, Luxembourg. 
Celine, D.-Garnsey, E. (2000) Emergence and Growth of High Tech Activity in Cambridge and Grenoble. Entrepreneurship and Regional Development. 12. 163-177. o.

Clarysse, B.-Wright. M.-Lockett, A.-van de Velde, E.-Vohora, A. (2005) Spinning out Nem Ventures: A Typology of Incubation Straregies from European Research Institutions. Research Policy. 2. 183-216. o.

Dóry T.-Rechnitzer J. (2002) Regionális innovációs stratégiák. Oktatási Minisztérium, Budapest.

Etzkowitz, H.-Webster, A.-Gebhardt. C.-Terra, B.R.C (2000) The future of the university, the university of the future: evolution of ivory tower to entrepreneurial paradigm. Research Policy. 2. 313-330. 0 .

Goldstein, H.A.-Renault, C.S. (2004): Contributions of Universities to Regional Economic Development: A Quasi-Experimental Approach. Regional Studies. 7. 733-746. o.

Hackett, S.M.-Dilts, D.M. (2004a) A Real Options-Driven Theory of Business Incubation. The Journal of Technology Transfer. 1. 41-54. o.

Hackett, S.M.-Dilts, D.M. (2004b) A Systematic Review of Business Incubation Research. The Journal of Technology Transfer. 1. 55-81. o.

Imreh Sz. (2005) Vállalkozásfejlesztés, mint a kis-és középvállalkozások hálózarosodásának ösztönzése. PhD értekezés. SZTE GTK, Szeged.

Inzelt A. (2004) The Evolution of University - Industry - Government Relationships During the Transition. Research Policy. 6-7. 975-995. o.

Inzelt A.-Szerb L. (2003) Az innovációs aktivitás vizsgálata ökonometriai módszerekkel. Közgazdasági Szemle. 11. 1002-1021. o.

Kállay L.-Imreh Sz. (2004) A kis-és középvállalkozás-fejlesztés gazdaságtana. Aula Kiadó, Budapest.

Lalkaka, R. (1997) Lessons from International Experience for the Promotion of Business Incubation Systems in Emerging Economies. UNIDO Small and Medium Enterprises Programme Paper. 3.

Lalkaka, R. (2002) Technlogy Business Incubators to Help Build an Innovation-Based Economy. Journal of Change Management. 2. 167-176. o.

Lengyel B. (2004) A tudásteremtés lokalitása: hallgatólagos tudás és helyi tudástranszfer. Tér és Társadalom. 2. 51-71.0.

Lengyel 1. (2003) Verseny és terilleti fejlödés. Térségek versenyképessége Magyarorszägon. JATEPress, Szeged.

Lengyel I.-Rechnitzer J. (2004) Regionális Gazdaságtan. Dialóg Campus Kiadó, Budapest-Pécs.

Mian, S.A. (1996) Assessing Value-added Contributions of University Technology Business Incubators to Tenant Firms. Research Policy. 25, 325-335. o.

Mian, S.A. (1997) Assessing and Managing the University Technology Business Incubator: An Integrative Framework. Journal of Business Venturing. 12. 251-285. o.

Morgan, B. (2002) Higher Education and Regional Econonic Development in Wales: An Opportunity for Demonstrating the Efficacy of Devolution in Economic Development. Regional Studies. 1. 65-73. 0 .

Patik R.-Deák Sz. (2005) Regionális klaszterek feltérkćpezése a gyakorlatban. Tér és Társadalom. Megjelenés alatt.

Peňa, I. (2004): Business Incubation Centers and New Firm Growth int he Basque Country, Small Business Economics. 3-4. 223-236. o.

Piech, K.-Radosevic, S. (2006) Knowledge-Based Economy in Central and Eastern European Countrie's. Palgrave, London.

Rechnitzer J. (1998) Területi Stratégiák, Dialóg Campus Kiadó, Budapesı-Pécs.

Rice, M.P. (2002) Co-production of Business Assistance in Business Incubators. An Exploratory Study. Journal of Business Venturing. 17. 163-187. o.

Tornatzky, L.-Sherman, H.-Adkins, D. (2003) Inculating Technology Business. A National Benchmarking Study. National Business Incubation Association, Ohio, Athens.

Varga A. (2004) Az egyetemi kutatások regionális gazdasági hatásai a nemzetközi szakirodalom tükrében. Közgazdasági Szemle. 3. 259-275. o. 


\section{UNIVERSITY BUSINESS INCUBATION: OPPORTUNITIES IN LESS FAVOURED REGIONS \\ ZOLTÁN BAJMÓCY}

Present paper examines university business incubation (UBI) as an economic development tool that can enhance the relationship between universities and the local business sphere. The problem of setting up UBIs have gained attention in Hungary recently but the foreign best practices almost always derive from highly developed regions which makes them difficult to adapt.

This study first reviews the peculiarities of university-related incubation with special emphasis on the university-related services and the spin-off process. The second part shows the results of an empirical analysis carried out in the Szeged sub-region (Hungary) that examines the attitudes of local small enterprises towards university-related incubation. The third part points out the factors which are necessary to consider in our opinion when planning a UBI project in a less favoured region. 